Open Access

\title{
The financial structure of the Tunisian listed businesses: an application on panel data
}

\author{
Mohamed Soufeljil ${ }^{1}$, Asma Sghaier ${ }^{2 *}$, Zouhayer Mighri ${ }^{3}$ and Hanène Kheireddine ${ }^{4}$
}

\author{
* Correspondence: \\ asma_sghaier1983@yahoo.fr \\ 2the ISG Sousse, LaREMFiQ \\ University of Sousse, Sousse, Tunisia \\ Full list of author information is \\ available at the end of the article
}

\begin{abstract}
This article aims at analyzing the financial structure of the Tunisian listed companies in the stock exchange of Tunis (SET). The study focuses on 26 companies observed over a period of 6 years (2005-2010). Three representations of the behavior of funding are tested: The first considers that the firms implement a policy of debt with an objective of debt ratio target, the second presupposes the existence of a hierarchy of funding and divides the existence of a target ratio, the third assumes that firms issuing shares when market conditions are favorable and redeemed in the opposite case. The statistical tests validate better the first approach. In fact, the choice of financing of Tunisian businesses confirms the greatest explanatory power of an analysis based on the existence of a debt ratio target.
\end{abstract}

Keywords: Tiered funding, Debt ratio target, Market timing, Capital structure

\section{Background}

From a financial point of view, the objective of a business is to create value; which means being able to carry out an investment that reached a profitability rate exceeding the rate of profitability required considering risks. The literature on the choice of the financial structure actually began in 1958, a date on which Modigliani and Miller (MM) have published a first founder article. The financial structure of a company is determined by "the relative proportion of the debt and equity" in the liabilities of its balance sheet (Berk and DeMarzo 2008). This relative level is usually the subject of a decision on the part of the company. How is it influenced? This question is the starting point of the research of Modigliani and Miller that was carried out in 1950. Based on some assumptions, they have demonstrated in their first article that the financial structure of a company had no impact on its total value. A few years later, in 1963 and in a second article, Modigliani and Miller complemented their analysis by introducing the taxation as one of the leading market imperfections. When the financial difficulty is without cost, they suggest to browse to the maximum of indebtedness in order to take advantage of the benefits of tax saving. Miller (1977) expands the framework defined by Modigliani and Miller in integrating the taxes on the income of natural persons. In such a context, where we take into account both the corporate and personal taxation, Miller concludes that the debt has no impact on the value of the firm. For this last research, there is no optimal structure of the capital. In contrast, since the series of work of Modigliani and Miller, the theoretical reflection on the behavior of capital's structure

(C) The Author(s). 2017 Open Access This article is distributed under the terms of the Creative Commons Attribution 4.0 International License (http://creativecommons.org/licenses/by/4.0/), which permits unrestricted use, distribution, and reproduction in any medium, provided you give appropriate credit to the original author(s) and the source, provide a link to the Creative Commons license, and indicate if changes were made. 
of firms was significantly extended. In fact, three main theories have been developed to explain the financial structure of firms. The first theory called "trade-off", the second is referred to as the theory of hierarchical funding or "pecking order". These first two theories are considered, for more than long, as two theoretical frameworks of reference for researchers while studying the capital's structure of firms. The work of Becker and Wurgler (2002) leads to the emergence of a third theoretical analysis, known under the name of the modern theory of the firm or still under the acronym of "Market Timing Theory of Capital Structure". It is thanks to their work that many searches are based on this new theory of "market timing" in the study of the determinants of capital's structure of enterprises. First, our goal is to adopt the main explanatory factors of the structural variations observed in the levels of debt. Then, we will attempt to test the various models arising from each theory to determine which one that best matches the context of Tunisia. We have analyzed the structure of the capital of a sample of Tunisian listed companies in the light of different financial theories (Adedeji 1998, Bacha and Attia 2016).

The purpose of this article is to shed light on the determinants of capital structure for companies listed on the Tunisian Stock Exchange. We use panel data models to compare the theoretical and empirical results in the literature with the Tunisian market, study the dynamic behavior of debt and test the existence of an adjustment process towards a target debt level (Shleifer and Vishny 1997; Soufeljil et al. 2016b).

Our contribution is thus twofold. First, we add to the existent literature by focusing on the determinant factors of the capital structure of an emerging country, namely Tunisia.

In fact, studying the Tunisian case may be interesting in terms of policy recommendations for this country and other emerging countries presenting similar features such as bank-oriented financial systems and relatively small capital markets. Second, this paper contributes to the relatively limited literature on the dynamics of the capital structure. It checks out the existence of an adjustment process towards a target leverage in the Tunisian market.

The article is structured as follows. The second section presents the literature review and research hypotheses. The third section deals with the methodological choice. The fourth section presents the results and their discussions. The last section presents the conclusion.

\section{A summary of the theoretical literature}

The theory of compromise: (trade-off theory)

As a result of the work of Modigliani and Miller (1958 and 1963) on the financial structure of the capital of the company, various theories have been proposed to be released including the assumption of the perfect market. Among those, one quotes the theory of optimal ratio of debt. This approach is based on the concept of arbitration while taking into account the different costs such as the expenses of Bankruptcy, Myers (1984) and the costs of Agency, Jensen and Meckling (1976) and Jensen (1986). In this framework, an optimal debt ratio must be the result of an arbitration, the potential gains related to the indebtedness in one hand and the risks and costs that examined this same indebtedness on the other hand. In the framework of the traditional financial theories, the model of Modigliani and Miller (1958) shows that in the absence of taxation and perfect financial markets, the financial structure appears neutral against the market value of the company. Indeed, in the presence of taxes on corporations, Modigliani and Miller (1963) suggest a 
maximum debt to take advantage of the benefit provided by the tax economy while the financial difficulty is without cost. Miller (1977) expands the framework defined by Modigliani and Miller (1963) by integrating the taxes on the income of natural persons. In such context, where we take account of both the corporate and personal taxation, Miller (1977) concludes that the debt has no impact on the value of the firm. For this last reason, there is no optimal structure of the capital. In addition, the theoretical reflection concerning the problem of structure of capital has significantly progressed since the series of work of Modigliani and Miller (1963). The static theory of Trade-Off constitutes the first axis of development since these works. This theory also is known under the name of "theory of compromise" and "the theory of symmetric Arbitration" is an arbitration of the economy of taxation linked to the debt and the costs of bankruptcy due to excessive debt.

The theory of Trade-Off has an object to explain how to achieve an optimal structure of capital which maximizes the value of the company. It argues that the optimal level of debt is reached when the marginal benefit of tax attributable to the endettement is canceled by the corresponding increase of potential costs of agency and bankruptcy. Thus, taking into account the taxation and the costs of bankruptcy suggests the existence of an optimal ratio of debt. This point of equilibrium is reached when the marginal gain of an additional unit of debt is equal to its marginal cost. In the framework of this analysis, several researchers have presented arguments in favor of the static theory of Trade-Off and the existence of an optimal structure of the capital. DeAngelo and Masulis (1980) propose a model where there exists an internal optimal level of debt. They conclude that the marginal benefit of debt is much lower than the tax base that has decreased by the other non-monetary deductible loads. According to DeAngelo and Masulis (1980), the optimal level of debt is caused by the interactions between the different tax brackets induced by the tax treatment that is different from incomes, actions and obligations. In his article "The Capital Structure Puzzle" Myers (1984) stresses that the optimum debt ratio of the firm is often determined by a compromise between the costs and benefits of the debt while leaving the assets of the company fixed as well as its plans for investments. According to this author, the firm must substitute the debt to the own funds or the own funds to the debt to the point that the value of the enterprise will be maximized. Modigliani and Miller (1963) have found that the generation of tax gains is due to the tax-deductible loan interest, from the increase of the costs of financial distress associated with a high level of debts, from the reduction of costs of agency between leaders and shareholders and the increase in these between leaders and payable at the time of the establishment of debt (Myers 1977). According to Fama and French (1997), the funding structure has no impact on the value of businesses, even when several imperfections, such as taxation, are incorporated. Indeed, for these authors, the existence of a target ratio can only be conceived in a universe where the imperfections of markets are both substantial and generators of high costs (Hovakimian 2006; Hovakimian and Li 2011 and Huang 2009).

\section{An approach of a hierarchy of funding: (pecking-order)}

The hypothesis of the existence of a debt ratio on own optimal funds at the individual level is rejected by the models of "hierarchy". Always because of the information asymmetries between the agents both inside the company and outside of it, the latter follows a hierarchy of precise funding, dictated by the need of external founding's, and not by 
an attempt to find the structure of optimal capital. In fact, the hierarchical theory integrates the theory of information to propose a structure, in particular by the information asymmetries and the problems of signaling. The leaders are supposed to prefer the internal resources of funding. However, in the presence of internal insufficient resources, they favor the indebtedness to the detriment of the capital increase. The theory of tiered funding initially developed by Myers (1984) and Myers and Majluf (1984) is not based on an optimization of a debt ratio. The information asymmetries and the problems of signaling that affect the demand for external financing entail a prioritization of funding. This prioritization of financing is revealed by the preference of businesses for an internal funding (self-financing) to the loss of external financing. This hierarchy is expressed, however, differently and this is according to the objective pursued by the leader of the company. The latter may decide to act in function of his aversion to risk, either to maximize the wealth of shareholders or to act in his interest. In these two cases, the leader works to maximize the benefit of some of the members of the enterprise (Myers and Majluf 1984):

- In the case where the leader seeks to ensure the interest of the existing shareholders, he must then establish a hierarchy among the different sources of funding. Due to the strong asymmetry of information and problems of reporting associated with the Issuance of own funds, the preference of the mode of financing can be classified as follows: In the first place, there is a privilege to internal funds of the company on external ones. In the second place, the debt is preferred to own funds including the least risky possible debt (Myers and Majluf 1984). Then, the decreasing financial hierarchy presents itself as the self-financing, little risky debt, the risky debt and capital increase ultimately.

In order to maximize its usefulness, Myers (1984) defines an organizational surplus composed of various attributes (high salary, consumption of goods and services as staff, gratuities etc.). Given the relatively binding character concerning the organizational surplus and the activity of monitoring related to debt, the leader will establish the following hierarchy: the cash flow, the capital increase and finally the debt. Myers (1984) believes that this kind of behavior may be limited by the vigilance, more or less strict, of shareholders (Chniguir et al. 2017; Martínez-Ferrero et al. 2013).

The theory of the hierarchical funding has been developed by Myers (1984) as well as by Myers and Majluf (1984). These authors have shown that the choice of financing enterprises follows a hierarchical order which has as a primary purpose the maximization of the wealth of the existing shareholders while avoiding the costs related to the asymmetry of information and to the adverse selection. In fact, the company prefers the internal financing rather than the external one and debt to the issuance of shares.

The theory of hierarchical funding is based on two fundamental elements: the leader always seeks the interest of the existing shareholders, and the asymmetry of information. According to Myers (1984), the joint observation of these two principles follows the following assumptions: if the investors feel the value of the firm correctly, the leaders will refuse to issue new shares because some of the benefits of the investment project will be shared with the new shareholders. By contrast, if the investors overestimate the value of the firm, the leaders will then try to issue new shares; source of profit 
for the existing shareholders. Apart from the case of a recent and rapid growth of the firm, the new issuance of shares will then be seen as a negative signal by external investors. Therefore the price of the shares will tend to decrease during the announcement of their issuance. But, this issue of shares is regarded as a costly method of obtaining additional funds. Some firms would prefer not to even invest in a profitable project rather than to issue under-assessed shares.

\section{The theory of market timing}

In the framework of the neoclassical financial theories; the relaxation of simplifying assumptions of Modigliani and Miller (1958) has resulted in the development of financial theories say compromise. In fact, taking into account the taxation and the costs of bankruptcy suggest the existence of an optimal ratio of debt. This theoretical current is known under the name of the theory of compromise or "The static trade-off Theory". The second theoretical framework that helped to explain the financial behavior of firms is manifested in the theory of the hierarchical funding or "Pecking-Order-Theory" (pot). This current research initiated by Myers and Majluf (1984), consists of establishing a ranking between the funding. For example, favoring self-financing is put in the second row of the debt and is chosen as a last resort to the issuance of shares. The basic assumption that guides the financial reasoning of this theory is that of informational asymmetry. Recently, we are witnessing an emergence of a new theoretical framework initiated by the work of Becker and Wurgler (2002), known under the acronym of "Market timing Theory of Capital Structure". According to the theory of market timing, firms issue shares when the courses are high and repurchase it when the courses are in decline. Distinguished by "market timing" or "operation of arbitration on the net asset value"; the benefit is derived from a variance of courses. A simple concept is deducted ${ }^{1}$; It is that the financial structure of a company is the result, not of an intelligent choice of a debt/equity capital target, but of the accumulation of decisions taken in the past in function of the financial context of the moment: issuance of shares when the valuations are high and the context awardees is good, issuance of debts and redemption of shares when the values are low and the Fellowship is pressed (Oztekin and Flannery 2012).

If the leaders had in mind a debt/equity capital, the company which conducts a capital increase should go into debt in the movement to contribute its financial structure again toward this target ratio. This is not the case in the observed reality. In contrast, from 1968 to 1998, Becker and Wurgler (2002) showed that the companies with little debt were those which had conducted capital increases when their relating valuations were generous. In the same way, they revealed that $70 \%$ of the existing financial structure is explained by the decisions taken, for more than 10 years and therefore by the levels of relating valuations at that time. Becker and Wurgler (2002) have identified the primary determinant of the current financial structure in the light of the very pragmatic and opportunistic attitude of financial directors who only match the needs of investors. These requirements are summarized in the fact of issuing shares when the courses are senior, going into debt and redeem shares when the courses are low. Indeed, the theory of market timing is based essentially on the effect of timing of market on the capital structure. Through a literature review, it appears that there are two versions concerned with the behavior of timing. The first version assumes that economic agents are rational. Considering that the costs of adverse selection vary during the time, several 
researchers propose to explain the theory of market timing as a dynamic behavior of the model of Hierarchical theory (Lucas and McDonald 1990; Jensen 1986a, 1986b). These works highlight the relevance of the problems of informational asymmetry in the process of issuing shares.

According to the second version of the theory of market timing, the economic agents are irrational and firms issue shares when their prices are high and they redeem otherwise. Becker and Wurgler (2002) show that the financial structure of a company is the result, not of a conscious choice of a target ratio, but the accumulation of decisions taken in the past in function of the stock Context:

- Issuance of shares when the valuations are high and the stock context is favorable;

- Issuance of Debts and redemption of shares when the courses are weak and/or the stock market is depressed.

Following the work of Becker and Wurgler (2002), several types of research have focused on the following question: To what extent the considerations of market timing influence the decisions of business financing? (Huang and Ritter 2006; Welch 2004). The results obtained by these authors will be discussed under three strands: the relevance of the theory of market timing, its persistence in time and finally the biases likely to affect the proxies.

\section{Assumptions of the models of research}

The paper of B Al-Najjar and al (2016) aims to investigate the impact of ownership structure on dividend policy of listed firms in Turkey. Mainly, it attempts to uncover the effects of family involvement (through ownership and board representation), nonfamily blockholders (foreign investors, domestic financial institutions and the state) and minority shareholders on dividend decisions in the post-2003 period as it witnesses the major economic and structural reforms.

The empirical results show that foreign and state ownership are associated with a less likelihood of paying dividends, while other ownership variables (family involvement, domestic financial institutions and minority shareholders) are insignificant in affecting the probability of paying dividends. However, all the ownership variables have a significantly negative impact on dividend payout ratio and dividend yield. Hence, the paper presents consistent evidence that increasing ownership of foreign investors and the state, in general, reduces the need for paying dividends in the Turkish market (Pfister and Schwarger 2016).

\section{The embodiment (tang)}

The presence of tangible capital assets on the balance sheet of the company has a significant impact on the structure of its debt. In fact, the tangible assets constitute, for the shareholders, an important guarantee to the extent that they have a considerable liquidation value. This has for consequence reducing the information asymmetries between leaders and creditors and this allows an easier access to the debt of the company. Harris and Raviv (1990) have argued that firms with a large mass of tangible capital asset have a high liquidation value. This also explains their increased use of debt services. This variable can have two possible relations with the ratios of indebtedness. So depending on the model of "pecking order", it is 
negatively correlated while the model of "trade-off" envisages a positive relationship.

\section{The profitability (rent)}

The theory of "trade-off" shows a positive relationship of this variable with a ratio of debt to equity. Similarly the theory of "pecking order" provides a negative relationship between the two variables. In fact, this variable is established during the calculation of the ratio between the profit before taxes and interests and the total of assets (Berle and Means 1956; Bradley et al. 1984).

Several authors have demonstrated that the relationship between profitability and debt ratio is positive. This is explained by the presence of profitable indebted firms. These firms accept the problems caused by the "Free Cash Flow" and this is the reason why the resort to debt is necessary. This relationship has been widely criticized by several studies from which we include in particular those developed by Ozkan (2001), Fama and French (2005), Chen (2004), Delcoure (2006). These authors have considered that the most profitable firms are financed through their auto-financing.

\section{The size (size)}

Rajan and Zingales (1995), Ozkan (2001), Fama and French (2002), Zou and Xiao (2006), have indicated that the size may have a positive sign with a ratio of debt to equity. However, other authors as Titman and Wessels (1988) and Chen (2004) have presented a negative sign of size. Rajan and Zingale (1995) have suggested that there is a positive relationship between the ratio of debt and the size of firms. This positive relationship evokes the question on the importance of the costs of bankruptcy.

On the other hand, several authors have argued that this positive relationship can be explained by the fact that large firms tend to decrease the costs of Agency caused by problems relating to under-investment and to the substitution of assets. This leads to the increase of their levels of debt. Harri and Raviv (1991), Booth and Al (2001), Fama and French (2002), Zou and Xiao (2006) validate this positive relationship between the ratio of debt and the size of firms. However, few studies developed by Titman and Wessels (1988) and Chen (2004) have found a negative relationship between these two variables (Autore and Kovacs 2009).

\section{The opportunities for growth (OG)}

The relationship between the opportunities of growth and the ratios of indebtedness presents many mixed signs. Indeed, the studies of theory of "trade-off" assume a negative relationship (Graham 2000; Booth and $\mathrm{Al}$ 2001). Yet, others while supporting the "pecking order" theory assume a positive relationship. Firms with a rapid growth in their sales levels have tended to increase their operating assets in order to meet the needs arising from this growth. Most of the studies mentioned that there exists a negative relationship between the ratios of indebtedness of firms and their growth opportunities. Then, Graham (2000), Booth and Al (2001), Delcoure (2006) and other authors observe that companies with rapid growth level have very high investment opportunities which can increase the value of those firms. However, other studies have not found this negative relationship such as those developed by Chen (2004), Tang and Yang (2007).

\section{Economies of non-debt taxes (EINLD)}

A negative relationship is expected between the economies of non-debt taxes and the debt ratio. This relationship is verified by several empirical studies such as those 
developed by: Titman and Wessels (1988), Ozkan (2001), Chen (2004) and N. Delcoure (2006). Several investments have led to savings of taxes and savings generated by debtedness. A negative relationship is expected between this variable and the levels of indebtedness.

\section{The liquidity (LIQ)}

Firms with a high liquidity ratio may have a high indebtedness ratio also thanks to their capacity to meet their commitments, a positive relationship is expected between the two variables. In other words, those firms can be supported by the importance of current assets which are to their provisions to finance their investments. This causes a negative relationship between these two variables.

\section{The risk of default (RD)}

Several types of research consider that there is a negative relationship between the risk of default and the ratio of debt to equity, (Fama and Frensh 2002; Zou and Xiao 2006). This variable is the expected sign for the two theories.

\section{The deficit of funding (DEF)}

According to Frank and Goyal (2003), Kayhan and Titman (2006), this variable plays a central role in the explanation of the effect of the Hierarchical funding. More specifically, it can be defined as the sum of investments, dividends, and change in working capital decreased net cash-flow. This amount is also equal to the sum of net emissions of debts and shares. Shyam and Myers (1999), Frank and Goyal (2003), Kayhan and Titman (2006) assert that with following the assumptions of the theory of "pecking order", the debt is the source of an original financing. Also, the companies with a significant deficit of funding increase their levels of debt. It is for this reason that there is a positive relationship between deficits of funding and ratios of indebtedness.

\section{The ratio $M T B$}

From the study prepared by Becker and Wurgler (2002), we assume that firms tend to issue new shares when their current stock prices are high and take advantage of the opportunities offered by the stock market. Opportunities allow firms to finance themselves through lower costs and increase their capacity of indebtedness. This ratio of debt is considered as a variable that captures the attempts of "timing" carried out by firms ina short term. A negative relationship is expected for this ratio. The leaders of companies will try to take advantage of the increase in their stock prices to finance themselves on the stock market and to enhance its capacity of debt.

\section{The weighted average of ratio of MTB}

A negative relationship is expected for this variable. Besides, this dependence is verified in the study prepared by Becker and Wurgler (2002), as well as in the theory of "market timing".

\section{The index of performance of stock exchange of Tunis (IPSET)}

We introduced this variable to test the existing relationship between debt ratios and performance within the stock exchange of securities. According to Frank and Goyal (2005), a negative relationship is expected between these two variables. Thus, in accordance with the theory of "market timing," when the conditions on the stock 
markets are favorable, the companies will try to take advantage of this situation in order to finance themselves at lower costs.

The aim of the paper of Kouki and Guizani (2009) is to identify and analyse the influence of shareholder ownership identity on dividend policy for a panel of Tunisian firms from 1995 to 2001. Their results indicate that Tunisian companies with highly concentrated ownership distribute more dividends. They find that there is a significant negative correlation between institutional ownership and distributed dividend level. The relation between dividend policy and state ownership is positive.

The paper of Zeriaa and Noubigh (2015) investigates the determinants of capital structure based on a panel of 32 non-financial companies listed on the Tunisian Stock Exchange over the period 2005-2010. The study is made concerning different theories of capital structure, namely the trade-off, pecking order and market timing theories with focusing on the impact of market imperfections on debt ratio. Both static and dynamic panel data regressions are performed and the empirical results reveal that firmspecific factors such as firm size and profitability influence capital structure choice in Tunisia, while no meaningful effect is detected for growth opportunities. Her results also show that Tunisian listed companies adjust towards a target debt ratio. The adjustment appears to be slow on the Tunisian market because of high adjustment costs.

\section{Data \& Methodology}

In the case of Tunisia, Dr. Soufeljil and al (2016a) showed that Tunisian companies first resort to debts that are mainly short-term, then self-financing and rarely to the issuance of new shares. Aware of the insufficient work on the determinants of the financial structure of Tunisian companies, we will try, in this work, to make a contribution in this direction.

Our objective is to understand the determinants of the financial structure of the Tunisian listed companies, in particular the enterprises of the two pillars of the national economy namely: Industry and trade. To do this, we propose to test empirically the theory of compromise and that of the hierarchical preferences of financing by trying to see:

- If companies go into debt because, they are seeking to achieve an optimum debt ratio; or

- If companies go into debt because, they having tiered funding preferences; or

- If companies go into debt both because, they are seeking to reach a target level of debt and because they prioritize their funding resources.

The dynamic model of the theory of the "Trade-Off."

The dynamic model of theory of target ratio is as follows:

$$
\begin{aligned}
\mathbf{D}_{\mathbf{i t}}= & \boldsymbol{\delta}_{0}+(1-\mathbf{\alpha}) \mathbf{D}_{\mathbf{i t}-1}+\boldsymbol{\delta}_{1} \text { TANG }_{\mathbf{t}}+\boldsymbol{\delta}_{2} \text { RENT }_{\mathbf{t}}+\boldsymbol{\delta}_{3} \text { TAILLE }_{\mathbf{t}}+\boldsymbol{\delta}_{4} \mathbf{O G}_{\mathbf{t}} \\
& +\boldsymbol{\delta}_{5} \text { EINLD }_{\mathbf{t}}+\boldsymbol{\delta}_{6} \mathbf{L I Q}_{\mathbf{t}}+\boldsymbol{\delta}_{7} \mathbf{R D}_{\mathbf{t}}+\boldsymbol{\varepsilon}_{\mathbf{i t}}
\end{aligned}
$$

\section{Sample and data source}

To validate the models of "Trade-Off" and of "pecking order", we have chosen a sample that is decomposed into 26 Tunisian firms listed on the stock exchange of Tunis. These firms belong to industrial, commercial and services sectors. In fact, financial firms are excluded from our sample because there is a risk of homogenization of data. In this 
regard, these companies have a financial structure that is different from that of the non-financial businesses. The data used in this research are derived primarily from the stock exchange of Tunis. The study period extends from 2005 to 2010 (6 years).

The industrial, commercial and service sectors are represented on the stock exchange of Tunis by 26 companies. Fourteen are large and listed on the main market, 11 are medium-sized companies listed on the market development and one is medium-sized listed on the growing market.

The choice of these companies is justified by the availability of accounting information on listed companies. There is no accessible database that centralizes the accounting information of unlisted Tunisian companies; and by the fact that this work is part of the research project on the evaluation of the reform process and the efficient upgrading of Tunisian companies by 2020. Only companies in the industrial, and services are retained. We chose only those companies for which we have at least five fiscal years. No sampling methodology was used due to the limited number of listed companies in the industrial, commercial and service sectors and for which we have at least five financial years.

\section{The dependent variables}

The choice of debt ratio has been the object of some theoretical studies. In addition, several authors argue that this ratio must be calculated from the book value of the debt. It is equal to the total value of assets less the book value of own funds. While others observe that it is the market value of debt which must be taken into account and that is obtained by substituting the accounting value of own funds by a market value. Several authors use these two measures at the same time as the studies developed by Becker and Wurgler (2002), Fama and French (2002), Kayhan and Titman (2006) and Frank and Goyal (2008). As well as other authors DeMiguel and Pindado (2001), Chen (2004) and Delcoure (2006) have limited their works to the book value of debt ratio as a result of the shortcomings of data. In fact, concerning our empirical study, we will work on the book value of debt ratio because there is also no sufficient data and we will use throughout this research two types of ratios to know: the ratio of total indebtedness which is equal to the carrying value of debt divided by the total assets and the debt ratio in the long term that is equal to the long-term borrowing on the total assets. We will adopt the same dependent variable for the two models to know the theory of "Trade-Off" and that of the theory of "pecking order".

\section{The independent variables}

The explanatory variables of the model of the theory of "trade-off "

\section{The embodiment of assets:}

According to Harris and Raviv (1991), Rajan and Zingales (1995) and Delcoure (2006), the embodiment is equal to the ratio between the sum of the tangible capital assets and stocks, divided by the total assets.

\section{Profitability}

This variable is measured by: 


$$
\text { RENT }=\frac{\text { Profits before interests and taxes }}{\text { Total Assets }}
$$

Size

To approximate this variable, we will use the natural logarithm of total assets.

\section{Opportunities for growth}

The ratio between the tangible assets and the total of assets are used for the approximation of this variable.

The economies of taxes not related to the debt

This variable is measured by:

$$
\text { EINLD }=\frac{\text { Endowments to amortization and to provisions }}{\text { Total assets }}
$$

\section{Liquidity}

This variable is introduced by Ozkan (2001), the two signs are expected signs.

$$
\mathbf{L I Q}=\frac{\text { Current Assets }}{\text { Current liabilities }}
$$

\section{The risk of default}

This variable is measured by:

$$
\mathbf{R D}=\frac{\text { Financial Charges (expenses) }}{\text { Profits before taxes and interests }}
$$

\section{Methods}

The explanatory variables of the mode of theory of "pecking order"

- The Funding Gap:

Following the theory of the "pecking order", the coefficient of this variable is equal to the unit. This variable s calculated as follows:

$$
\mathbf{D E F}=\mathbf{I}+\mathbf{D}+\Delta \mathbf{F R}-\mathbf{C F}
$$

With:

I: investment of the company during the year t;

D: dividends paid by the company during the year $t$;

$\Delta$ FR: variation in the bottom of the bearing $(F R=$ Current Assets - Current Liabilities);

CF: net cash flow is equal to results of holdings after the payment of taxes and interests. 
The independent variables

The model discussed during this section contains four new variables: the ratio of MTB, the weighted average of the MTB ratios, the index of performance of securities in Tunis and rate of the financial market (Huang and Ritter 2005, 2006).

\section{The ratio MTB}

This variable is approximated as follows:

$$
\text { MTB }=\frac{\text { Market capitalization }+ \text { debts }}{\text { Net Assets }}
$$

The weighted average of the ratio of MTB (EFWMB)

According to Becker and Wurgler (2002), this variable is regarded as being the best approximation of the persistence of attempts of timing. This weighted average is used to test the persistence of the effect of attempts of timing in the structures of financing of businesses.

This ratio is calculated as follows:

$$
\mathbf{E F W M B}=\sum_{\mathbf{s}=1}^{\mathbf{t}-1} \frac{\mathbf{e}_{\mathbf{s}}+\mathbf{d}_{\mathbf{s}}}{\sum_{\mathbf{r}=1}^{\mathbf{t}-1}\left(\mathbf{e}_{\mathbf{r}}+\mathbf{d}_{\mathbf{r}}\right)} \times \mathbf{M T B}_{\mathbf{s}}
$$

EFWMB: The weighted average of ratio of MTB for the period $t$ - 1;

Es: net emissions of shares during the period s;

Ds: net emissions of debts during the period s;

MTBs: The ratio of Market to book relating to the year s.

The index of performance of the stock exchange of Tunis (IPSET)

It is a price index (simple arithmetic average of courses).

\section{The rate of monetary market}

The rate of borrowing on the market is indexed by the TMM. It is the average of the last twelve monthly average rates of the monetary market of Tunisia before the date of payment of interest. After quoting different theoretical journals on the capital structure as well as the recent empirical works, this part focuses on the choice of funding of Tunisian firms and their abilities to return to the target ratio of debt.

\section{Results and discussions}

Tests that will be filed; deposited are based on estimates of panel data. All these estimates will be carried out thanks to the Software" STATA 11 "A study made by Kennedy (1985), affirms the existence of a problem of multicollinearity if and only if, the Pearson correlation coefficients exceeds $(0,8)$. In fact, the matrix of Pearson is given by the following Table 1 .

We note well, after this correlation matrix of explanatory variables, that there is no problem of multicollinearity between the variables studied. (All the coefficients do not exceed 0,8$)$. 
Table 1 Correlation coefficients of the explanatory variables

\begin{tabular}{llllllll}
\hline & Tang & Rent & Size & Og & Liq & Rd & Einld \\
\hline Tang & 1.000 & & & & & & \\
Rent & -0.569 & 1.000 & & & & & \\
Size & -0.403 & 0.284 & 1.000 & & & & \\
Og & 0.237 & -0.293 & -0.084 & 1.000 & & & \\
Liq & 0.289 & 0.150 & -0.391 & -0.228 & 1.000 & & \\
Rd & -0.079 & 0.093 & 0.101 & -0.074 & -0.013 & 1.000 & \\
Einld & -0.595 & 0.274 & -0.023 & -0.134 & 0.082 & 0.168 & 1.000 \\
\hline
\end{tabular}

\section{The empirical validation of models of "trade-off" and the" pecking order"}

In this first section, we prove the models of the theory of "Trade-Off" and those of "pecking order". Then, we will present three models. The first is devoted to the static version of theory of "Trade-Off" while the second one is used to test the dynamic version of this theory of "Trade-Off". Finally, the third allows you to check the theory of "pecking order".

\section{The static model of theory of "Trade-off"}

After performing the stationarity tests for all the series included in the model, we found that most of the series are stationary in level; this explains the use of stationary panel data. The first interest is to determine the tests of specification or tests of homogeneity of the data.We are going to go up if the considered model is entirely identical to all firms in the sample or if there are specific features of each firm. The results based on the statistics of Fisher show the rejection of the hypothesis of global homogeneity knowing that there are common coefficients for all firms as well as the presence of individual specificities for each firm $(P$-value $<10 \%)$. We have used the method of panel data. A problem of multicollinearity is present in a regression when an explanatory variable is close to a linear combination of at least one other explanatory variable. When the multicollinearity is perfect and we cannot obtain an estimate of the parameters. For this, audits are required to be ranging from the simple correlation matrix of the explanatory variables to other statistics such as the inflation factor of the variance (VIF), the most used indicator by software (Joeveer 2013; Kötter et al. 2009).

Variance Inflation Factors (VIF) provide a measure of the increase in the variance of the estimated regression coefficients with respect to a situation where the prediction variables do not have a linear relationship. They allow describing the importance of multicollinearity (correlation between predictors) in a regression analysis. Multicollinearity is problematic because it can increase the variance of the regression coefficients, making them regressive and difficult to interpret.

We can use the VIF command after the regression to check for multicollinearity. VIF stands for the variance inflation factor. As a rule of thumb, a variable whose VIF values are greater than ten may merit further investigation. Tolerance, defined as $1 / \mathrm{VIF}$, is used by many researchers to check on the degree of collinearity. A tolerance value lower than 0.1 is comparable to a VIF of 10. It means that the variable could be considered as a linear combination of other independent variables.

The investigation of the results indicates that the problem of multicollinearity is not serious in our case since the VIF is lower than 3. However, it seems that there is a 
collinearity that is relatively disturbing between variables Tang and einld with keen above 2. By eliminating one of the two variables in the regression, the collinearity issue will be resolved. By eliminating the variable einld, the regression indicates that the variable einld is not significant to thresholds of the usual risks. The estimation of the model by data from Panel allows you to control the heterogeneity of the variables in their individual quantities. The estimation of fixed effects uses the differences to the individual averages and eliminates the consistent differences between the companies. This method allows identifying and measuring the effects which are not directly identifiable. Thus, the random effects model assumes the independence between terms of errors and explanatory variables (Dang et al. 2014) (Table 2).

The test of Hausman (1978) allows you to validate the exogeneity of the specific effect in relation to the independent variables. For the two models, the estimates by the ordinary least squares (OLS) are biased and the probability of the test specification of Hausman is greater than the threshold of $10 \%$. Nevertheless, the test of Hausman does not differentiate between the fixed-effects model and the random effects model. Besides, (R2 within $<$ R2 between) has led us to promote the random effects model for the two ratios of indebtedness. The same is considered for the two ratios of debt, the probability of Statistics of the test of Breush-Pagan (1979) shows that there is no problem of heteroscedasticity. Furthermore, the test of Wooldridge (2002) indicates that there is no problem of the first-order autocorrelation in tailings for both ratios of debt. We can note that the model used explains well the levels of indebtedness of Tunisian businesses listed on the stock exchange of Tunis and this is for the two versions of indebtedness designated. In fact, for the ratio of total indebtedness the coefficient of determination is 0.9151 , while for long-term debt ratio this coefficient is 0.8915 .

The tangibility variable is significant at the threshold of $1 \%$ in all of the estimated models. This variable is positively correlated with the debt ratios. This result is affirmed by Harris and Raviv (1991), Rajan and Zingales (1995) and Delcoure (2006). In other words, the Tunisian businesses with a large mass of tangible capital assets have a high liquidation value. This explains their increased use of services of debt.

The variable profitability is also significant at the threshold of $1 \%$ for the model of the ratio of total indebtedness and significant contribution to the $10 \%$ threshold for the model of debt ratio in the long the term. This variable is negatively correlated with the debt ratios. This result is confirmed by several authors (Shyam and Myers 1999; Fama and French 2002; Chen 2004). The negative correlation between these two variables means that the more firms are profitable the more their debt levels are

Table 2 Coefficients of the variables correlation of the variables

\begin{tabular}{llllllll}
\hline & Tang & Rent & Size & Mtb & Efwmb & IPSET & Tmm \\
\hline Tang & 1.000 & & & & & & \\
Rent & -0.569 & 1.000 & & & & & \\
Size & -0.403 & 0.284 & 1.000 & & & & \\
Mtb & 0.665 & -0.501 & -0.277 & 1.000 & & & \\
Efwmb & 0.352 & -0.385 & -0.195 & 0.496 & 1.000 & & \\
IPSET & -0.038 & 0.118 & -.002 & -0.047 & -0.018 & 1.000 & \\
Tmm & 0.014 & -0.059 & -0.066 & -0.076 & 0.000 & -0.033 & 1.000 \\
\hline
\end{tabular}


falling. Thus, this variable holds significant and high coefficients (for the ratio of total indebtedness these coefficients vary between -1.161 and -1.149 and between $-0,224$ and $-0,218$ for debt ratio in long term). Then, levels of indebtedness of Tunisian firms are influenced negatively by their profitability.

The variable size is positively correlated with the dependent variable. This latter variable is consistent with the assumptions of several journals of literature (Booth et al. 2001; Fama and French 2002; Delcoure 2006). This variable is significant at the $5 \%$ threshold in all the estimated models. The positive relationship means that the more the size of firms is high their probabilities of bankruptcy is low. But, this variable affects more debt ratios totals than those in the long term. In effect, their coefficients are between 0,057 and 0,058 for the ratio of total debt and between 0,044 and 0,046 for debt ratio in long term.

The variable relative to the liquidity is significant at the threshold of $1 \%$ for all the estimated models. This variable is negatively correlated with both ratios of debt. This negative relationship means that the Tunisian firms having several liquid assets, have tended to use it for their financial investments. In fact, the coefficient is equal to $-0,026$ for the ratio of total debt and equal also to $-0,031$ for debt ratio in the long term. As regards to the other variables, they are not significant. It is to say that the Tunisian firms do not give a particular thought to these factors.

\section{The dynamic model of the theory of the "Trade-Off"}

A dynamic model is a model in which one or several delays of the dependent variable are included as explanatory variables. When econometric techniques standards as the OLS do not allow obtaining efficient estimates of such a model, it is to estimate on Panel Data dynamic. This form of estimation is based on the estimator of Arellano and Bond (1991) which is the most effective thanks to the dependent delayed variable located to the right of the equation.

The Estimator by the method of generalized time (GMM) in first difference of Arellano and Bond (1991) is to take for each period the first difference of the estimated equation. To eliminate the specific effects of countries, we instrumented the explanatory variables of the equation in first difference by their values at the delayed level of a period or more (Chirinko and Singha 2000) (Table 3).

Table 3 The coefficients of correlation of variables

\begin{tabular}{|c|c|c|c|c|c|c|c|c|c|c|}
\hline & Tang & Rent & Size & $\mathrm{Og}$ & Liq & $\mathrm{Rd}$ & Def & Mtb & Efwmb & IPSET \\
\hline Tang & 1.000 & & & & & & & & & \\
\hline Rent & -0.569 & 1.000 & & & & & & & & \\
\hline Size & -0.403 & 0.284 & 1.000 & & & & & & & \\
\hline $\mathrm{Og}$ & 0.237 & -0.293 & -0.084 & 1.000 & & & & & & \\
\hline Liq & 0.289 & 0.150 & -0.391 & -0.228 & 1.000 & & & & & \\
\hline $\mathrm{Rd}$ & -0.079 & 0.093 & 0.101 & -0.074 & -0.013 & 1.000 & & & & \\
\hline Def & 0.098 & -0.164 & -0.428 & From 0.099 & 0.089 & -0.115 & 1.000 & & & \\
\hline Mtb & 0.665 & -0.501 & -0.277 & 0.363 & 0.022 & -0.152 & 0.026 & 1.000 & & \\
\hline Efwmb & 0.352 & -0.385 & -0.195 & 0.168 & -0.005 & -0.097 & 0.061 & 0.496 & 1.000 & \\
\hline IPSET & -0.038 & 0.118 & -.002 & 0.000 & -0.012 & -0.025 & -0.155 & -0.191 & 0.000 & 1.000 \\
\hline
\end{tabular}


Although it is asymptotically more efficient, the GMM estimator in two steps leads to biased results. In effect, for the two indebtedness ratios the GMM estimator in the two stages is not effective since the coefficient associated with the lagged dependent variable is not significant for debt ratio in the long term. In this regard, this coefficient gives a higher value to the unit for ratio of total debt. Similarly, the majority of explanatory variables are not significant. Then, we can choose the estimator of a step for both ratios of debt.

Two tests are associated to the estimator of GMM in the dynamic panel. The first test is the test of over-identification of Sargan/Hansen that allows you to test the validity of lagged variables as an instrument. The second test $C$ is also the test of the autocorrelation of Arellano and Bond (1991) where the null hypothesis is the absence of autocorrelation of a second errors' order of the equation in difference. In fact, the test of Hansen ( $p=1.000$ for the two ratios of debt), the test of Sargan (for the ratio of total indebtedness $p=0.019$ and for debt to equity ratio of long-term $P=0.035$ ) and the test of autocorrelation of second order of Arellano and Bond (1991) (for debt ratio total $P=0.004$, for the debt to equity ratio of long-term $p=0.017$ ) do not allow to reject the hypothesis of validity of the lagged variables as an instrument, and the hypothesis of the absence of autocorrelation of a second order.

The positive coefficients are always significant at the threshold of $1 \%$ of the delayed variable. This confirms the existence of adjustment costs on the Tunisian market. The coefficient for adjustment of target ratio being equal to (1- $\mathbf{\alpha})$ with $\boldsymbol{\alpha}$ as the coefficient of the delayed variable of debt. In fact, these adjustment costs are equal to 0.003 for the ratio of total indebtedness and 0.031 for a debt ratio in the long term. These values demonstrate that the Tunisian firms adjust their indebtedness ratios in a low way in order to achieve their target levels. This result is contradictory to the result obtained in the Studies of DeMiguel and Pinaldo (2001) (whose speed is equal to 0.79), Shyam and Myer (1999) (this speed is equal to 0.41) and Ozkan (2001) (whose speed is equal to 0.47).

Hertig (1998) has analyzed the variations in the financial structures of Swiss companies. This speed is due to the shortcomings in procedures of internal and external control of credit institutions. In fact, we also note that the credit policies of Swiss banks are focused on personal relationships.

The representative variables of embodiment, profitability and size are significant at the threshold of $1 \%$ for two dependent variables. This is confirmed by the results obtained in the static model. In another word, the liquidity variable is significant at the threshold of $1 \%$ for both ratios of debt. In addition, the variable risk of default is significant at $5 \%$ threshold for the two ratios of debt. Nevertheless, the influence of these variables is very limited due to the low value of the associated coefficient (Barclay and Smith 1995; Benito 2003).

\section{The model of theory of "pecking order"}

The model of the theory of tiered funding is as the follows:

$$
\mathbf{D}_{\mathbf{i t}}-\mathbf{D}_{\mathrm{it}-1}=\mathbf{\alpha}_{0}+\mathbf{\alpha}_{1} \mathrm{DEF}_{\mathrm{it}}+\boldsymbol{\varepsilon}_{\mathrm{it}}
$$

The study of this model will be executed similarly to the one developed for a static model of the theory of "Trade-Off" (Table 4).

In summary, the results do not allow us to reject the hypothesis of the presence of a tiered funding under its form semi-strong. The model is broadly significant at a 5\% threshold for the majority of tested regressions. As well, we can note that the model used is unable to 
Table 4 Summary of the results of regressions carried out in the static model of Trade-Off

\begin{tabular}{|c|c|c|c|c|c|c|}
\hline \multirow[t]{2}{*}{ The variables } & \multicolumn{3}{|c|}{ Ratio of total indebtedness } & \multicolumn{3}{|c|}{ Long-term debt-to-equity } \\
\hline & Ols & $E F$ & EA & Ols & EF & EA \\
\hline Tang & $\begin{array}{l}0.343 \\
(0.023)^{\mathrm{a}}\end{array}$ & $\begin{array}{l}0.340 \\
(0.024)^{a}\end{array}$ & $\begin{array}{l}0.343 \\
(0.023)^{a}\end{array}$ & $\begin{array}{l}0.270 \\
(0.020)^{a}\end{array}$ & $\begin{array}{l}0.267 \\
(0.020)^{a}\end{array}$ & $\begin{array}{l}0.270 \\
(0.020)^{\mathrm{a}}\end{array}$ \\
\hline Rent & $\begin{array}{l}-1.149 \\
(0.135)^{\mathrm{a}}\end{array}$ & 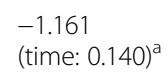 & $\begin{array}{l}-1.149 \\
(0.134)^{\mathrm{a}}\end{array}$ & $\begin{array}{l}-0.218 \\
(0.116)^{c}\end{array}$ & $\begin{array}{l}-0.224 \\
(0.131)^{c}\end{array}$ & $\begin{array}{l}-0.218 \\
(0.116)^{c}\end{array}$ \\
\hline Size & $\begin{array}{l}0.057 \\
(0.022)^{b}\end{array}$ & $\begin{array}{l}0.058 \\
(0.022)^{b}\end{array}$ & $\begin{array}{l}0.057 \\
(0.022)^{\mathrm{b}}\end{array}$ & $\begin{array}{l}0.044 \\
(0.019)^{b}\end{array}$ & $\begin{array}{l}0.046 \\
(0.019)^{\mathrm{b}}\end{array}$ & $\begin{array}{l}0.044 \\
(0.019)^{\mathrm{b}}\end{array}$ \\
\hline Oc & $\begin{array}{l}2.804 \\
(2.277)\end{array}$ & $\begin{array}{l}2.881 \\
(2304)\end{array}$ & $\begin{array}{l}2.804 \\
(2.277)\end{array}$ & $\begin{array}{l}-0.506 \\
(1954)\end{array}$ & $\begin{array}{l}-0.384 \\
(1.975)\end{array}$ & $\begin{array}{l}-0.506 \\
(1954)\end{array}$ \\
\hline Liq & $\begin{array}{l}-0.026 \\
(0.009)^{\mathrm{a}}\end{array}$ & $\begin{array}{l}-0.025 \\
(0.009)^{a}\end{array}$ & $\begin{array}{l}-0.026 \\
(0.009)^{\mathrm{a}}\end{array}$ & $\begin{array}{l}-0.031 \\
(0.008)^{a}\end{array}$ & $\begin{array}{l}-0.030 \\
(0.008)^{\mathrm{a}}\end{array}$ & $\begin{array}{l}-0.031 \\
(0.008)^{\mathrm{a}}\end{array}$ \\
\hline $\mathrm{Rd}$ & $\begin{array}{l}-0.025 \\
(0.017)\end{array}$ & $\begin{array}{l}-0.027 \\
(0.017)\end{array}$ & $\begin{array}{l}-0.025 \\
(0.017)\end{array}$ & $\begin{array}{l}-0.028 \\
(0.014)^{c}\end{array}$ & $\begin{array}{l}-0.029 \\
(0.015)^{c}\end{array}$ & $\begin{array}{l}-0.028 \\
(0.015)^{c}\end{array}$ \\
\hline _Cons & $\begin{array}{l}-1.006 \\
(0.416)^{b}\end{array}$ & $\begin{array}{l}-1.025 \\
(0.421)^{b}\end{array}$ & $\begin{array}{l}-1.005 \\
(0.416)^{\mathrm{b}}\end{array}$ & $\begin{array}{l}-0.746 \\
(0.357)^{b}\end{array}$ & $\begin{array}{l}-0.784 \\
(0.362)^{\mathrm{b}}\end{array}$ & $\begin{array}{l}-0.746 \\
(0.357)^{\mathrm{b}}\end{array}$ \\
\hline R2 adjusted & 0.8364 & 0.8364 & 0.8364 & 0.7096 & 0.7095 & 0.7096 \\
\hline R2 within & - & 0.8349 & 0.8348 & - & 0.7068 & 0.7067 \\
\hline R2 between & - & 0.9129 & 0.9151 & - & 0.8869 & 0.8915 \\
\hline $\mathrm{F}$ & $121.85^{\mathrm{a}}$ & $116.27^{\mathrm{a}}$ & & $58.23^{\mathrm{a}}$ & $55.44^{\mathrm{a}}$ & \\
\hline Wald & - & - & $731.13^{\mathrm{a}}$ & - & - & $349.36^{\mathrm{a}}$ \\
\hline $\mathrm{H}$ & - & 0.60 & & - & 1.18 & \\
\hline LM & - & - & 1.18 & - & - & 0.98 \\
\hline M1 & - & - & 9.121 & - & - & 0.939 \\
\hline N & 150 & 150 & 150 & 150 & 150 & 150 \\
\hline
\end{tabular}

Source: estimate done

${ }^{a}$ Significant at the $1 \%$ level

${ }^{\mathrm{b}}$ Significant at the threshold of $5 \%$

'Significant at the threshold of $10 \%$

$\mathrm{F}$ is a test of overall significance of Fisher; Wald is a Wald test of the joint significance of the variables specific to firms;

$\mathrm{H}$ is a test of a specification of Hausman; LM is a test of heteroscedasticity of Breush-Pagan;

$\mathrm{M} 1$ is a test of autocorrelation of order 1 of Wooldridge; the standard deviations are carried over between parentheses

explain the levels of indebtedness of Tunisian firms listed on the stock exchange of Tunis. In fact, the coefficients of determination vary between 0.007 and 0.0421 for the ratio of total debt and between 0.0182 and 0.0751 for the debt ratio in the long term.

For the two models, the estimates by OLS are biased and the probability of test specification of Hausman is greater than the threshold of $10 \%$. However, the test of Hausman does not differentiate between the fixed-effects model and the random effects one. Thus, the ratio of total indebtedness ( $\mathrm{R} 2$ within $>\mathrm{R} 2$ between) has led us to promote the fixed-effects model. However, the debt ratio in the long term (R2 within $<$ r2 between) has led us to promote the random effects model. Indeed, even for the two ratios of debt, the probability of Statistics of the test of Breush-Pagan shows that there is a problem of heteroscedasticity. Similarly, the test of Wooldridge proves the existence of a problem of the first-order autocorrelation in tailings for both ratios of debt.

The variable of a deficit of funding is significant at $5 \%$ threshold for the ratio of total indebtedness, but it is not significant only at the threshold of $10 \%$ for the debt ratio in the long term. These results are similar to those of Shyam and Myers (1999), Frank and Goyal (2003), Kayhan and Titman (2006). 
Finally, we can conclude that the weakness of coefficients of determination which are very close to 0 allowed to check the lack of relevance in the theory of hierarchical funding in the context of Tunisia (Bias et al. 1995; Borisova et al. 2015; Boyd and Solarino 2016).

\section{The empirical validation of model of "market timing"}

The Table 2 shows that the correlation between the variables is average. Nevertheless, the MMR which reflects the cost of debt and the SET index which measures the performance of the stock market are weakly correlated. What has led us to exclude the variable TMM. As we have already seen in the previous section, all the tests have been carried out by data from the panel. Thus, the software used is the "STATA 11". All the models that have been analyzed previously are static models (Table 5).

The explanatory power of the tested models varies between 0,8663 and 0,9516 for the ratio of total debt and between 0,6887 and 0,8782 for the debt ratio in the long term. In comparison with the work of Becker and Wurgler $(2002)(\mathrm{r} 2=0,20)$ and Hovakimian (2006) $(\mathrm{r} 2=0.267)$ (Table 6).

On the other hand, a probability of the test specification of Hausman is greater than the threshold of $10 \%$ for the two models. Therefore, the test of Hausman does not differentiate between the fixed-effects model and the random effects one. As well, for the two models (R2 within < r2 between), we will promote the random effects model. In fact, the likelihood of statistics of the test of Breush-Pagan shows that there is a problem of heteroscedasticity for both ratios of debt. Similarly, the test of Wooldridge shows that there is a problem of the first-order autocorrelation in tailings for both ratios of debt.

The variables relating to embodiment, profitability and size always retain their significance at the threshold of $1 \%$ in all the estimated models. This significance is well used in the analysis of structures of the capital of Tunisian businesses.

Table 5 Estimation of adjustment toward a debt level target

\begin{tabular}{|c|c|c|c|c|}
\hline \multirow[t]{2}{*}{ The variables } & \multicolumn{2}{|c|}{ Ratio of total indebtedness } & \multicolumn{2}{|c|}{ Long-term debt-to-equity } \\
\hline & A step & Two Steps & A step & Two Steps \\
\hline$\overline{\text { Rdette_1 }}$ & $0.997(0.029)^{a}$ & $2.519(0.854)^{a}$ & - & - \\
\hline Rdlt_1 & - & - & $0.969(0.042)^{a}$ & $0.441(0.727)$ \\
\hline Tang & $-0.323(0.020)^{a}$ & $0.054(0.296)$ & $-0.274(0.018)^{a}$ & $-0.672(0.359)^{c}$ \\
\hline Rent & $0.623(0.147)^{a}$ & $-1.225(5.836)$ & 0 and $1.138(0.267)^{c}$ & $-4.537(4.199)$ \\
\hline Size & $-0.062(0.019)^{a}$ & $0.118(0.442)$ & $-0.062(0.018)^{a}$ & $-0.010(0.137)$ \\
\hline Og & $-2.126(1937)$ & - & $-0.398(1.812)$ & - \\
\hline Liq & $0.025(0.008)^{a}$ & $0.016(0.186)$ & $0.025(0.007)^{\mathrm{a}}$ & $0.267(0.3)$ \\
\hline $\mathrm{Rd}$ & $0.026(0.015)^{b}$ & $-0.081(0.221)$ & $-0.028(0.013)^{b}$ & $1.243(0.628)^{b}$ \\
\hline Wald & $1618.14^{\mathrm{a}}$ & $300.69^{a}$ & $867.15^{\mathrm{a}}$ & $261.51^{\mathrm{a}}$ \\
\hline Sargan & $160.14^{\mathrm{b}}$ & $160.14^{\mathrm{b}}$ & $155.10^{b}$ & $155.10^{\mathrm{b}}$ \\
\hline Hansen & 0.00 & 0.00 & 0.00 & 0.00 \\
\hline M2 & $-2.87^{b}$ & -1.05 & $-2.38^{\mathrm{b}}$ & 1.30 \\
\hline $\mathrm{N}$ & 132 & 132 & 132 & 132 \\
\hline
\end{tabular}

Indicates a significance level of $1 \%$

b Indicates a significance level of $5 \%$

Indicates a significance level of $10 \%$

Wald is a Wald test of joint significance of variables specific to firms; Sargan is a test of over-identification of restrictions which follows asymptotically an Act of $2 x ; M 2$ is a test of autocorrelation of Order 2 which follows asymptotically a law $\mathrm{N}(0.1)$; The standard deviations robust asymptotic to the heteroscedasticity are deferred in parentheses 
Table 6 Summary of the results of regressions carried out to the funding model hierarchy

\begin{tabular}{|c|c|c|c|c|c|c|}
\hline \multirow[t]{2}{*}{ The variables } & \multicolumn{3}{|c|}{ Ratio of total indebtedness } & \multicolumn{3}{|c|}{ Long-term debt-to-equity } \\
\hline & Ols & EF & EA & Ols & $\mathrm{EF}$ & EA \\
\hline Def & $\begin{array}{l}-3.949 \\
(1.677)^{b}\end{array}$ & $\begin{array}{l}-4.157 \\
(1.752)^{b}\end{array}$ & $\begin{array}{l}-3.949 \\
(1.677)^{b}\end{array}$ & $\begin{array}{l}-3.399 \\
(1.477)^{b}\end{array}$ & $\begin{array}{l}-2.218 \\
(1.573)\end{array}$ & $\begin{array}{l}-2.698 \\
(1.437)^{c}\end{array}$ \\
\hline _Cons & $\begin{array}{l}-1.84 e+07 \\
(2.38 E+07)\end{array}$ & $\begin{array}{l}-1.94 e+07 \\
(2.79 E+07)\end{array}$ & $\begin{array}{l}-1.84 \mathrm{E}+07 \\
(2.38 \mathrm{E}+07)\end{array}$ & $\begin{array}{l}-1.58 E+07 \\
(2.42 E+07)\end{array}$ & $\begin{array}{l}-1.03 E+07 \\
(2.15 E+07)\end{array}$ & $\begin{array}{l}-1.34 \mathrm{E}+07 \\
(3.59 \mathrm{E}+07)\end{array}$ \\
\hline R2 adjusted & 0.04 & 0.0400 & 0.0400 & 0.0389 & 0.0389 & 0.0389 \\
\hline R2 within & - & 0.0421 & 0.0421 & - & 0.0182 & 0.0182 \\
\hline R2 between & - & 0.0070 & 0.0070 & - & 0.0751 & 0.0751 \\
\hline $\mathrm{F}$ & $5.54^{\mathrm{b}}$ & $5.63^{\mathrm{b}}$ & - & $5.30^{\mathrm{b}}$ & 1.99 & - \\
\hline Wald & - & - & $5.54^{\mathrm{b}}$ & - & - & $3.53^{c}$ \\
\hline $\mathrm{H}$ & - & 0.17 & & - & 0.56 & \\
\hline LM & - & $1.41^{\mathrm{c}}$ & - & - & - & $12.12^{\mathrm{a}}$ \\
\hline M1 & - & $123.82^{\mathrm{a}}$ & - & - & - & $89650^{a}$ \\
\hline N & 135 & 135 & 135 & 133 & 133 & 133 \\
\hline
\end{tabular}

${ }^{\mathrm{a}}$ Significant at the $1 \%$ level

${ }^{\text {b }}$ Significant at the threshold of $5 \%$

'Significant at the threshold of $10 \%$

$\mathrm{F}$ is a test of the overall significance of Fisher; Wald is a Wald test of the joint significance of variables specific to firms;

$\mathrm{H}$ is a test of a specification of Hausman; LM is a test of heteroscedasticity of Breush-Pagan;

$\mathrm{M} 1$ is a test of autocorrelation of order 1 of Wooldridge; the standard deviations are carried over between parentheses

Similarly, the ratio of MTB has kept its importance at the threshold of $1 \%$ for both ratios of debt. In this regard, for the debt ratio in the long term, the negative sign of the coefficient confirms its negative impact on the levels of indebtedness of $\mathrm{Tu}$ nisian firms. But for the ratio of total indebtedness this coefficient has a positive but unexpected sign (Lenz and Al 2015).

The weighted average of MTB ratios is not significant and does not present even the expected sign. These results coincide with those of Leary and Roberts (2005) that suggest that the American firms tend to readjust their structures of capital towards the target levels of indebtedness. Similarly for Alti (2005), Flannery and Rangan (2006), Kayhan and Titman (2006) and Hovakimian (2006) who consider that the attempted effect of "timing" is limited to short term. These results are in contradiction with those obtained by Becker and Wurgler (2002) and those by Huang and Ritter (2006). The latter consider that assessment stock prices of companies have a persistent effect and a significant impact on structures of the capital of firms.

\section{Empirical validation of the combination of the various theories}

The majority of recent studies are devoted to the analysis of variations of structures of the capital of the companies. These studies consider that such a combination is necessary considering the complexity that surrounds the decisions related to the structures of capital. Hence, this last section will deal with the combination of various theoretical frameworks that we have already presented throughout this work (Table 7).

This correlation matrix of independent variables shows that there is no problem of multicollinearity between the studied variables,(all the coefficients do not exceed 0.8 ). The tests are developed using panel data through the software "STATA 11". All the models analyzed are static models. They use the methodology adopted in the first section. 
Table 7 Summary of the results of the regressions carried out the model of "market timing"

\begin{tabular}{|c|c|c|c|c|c|c|}
\hline \multirow[t]{2}{*}{ The variables } & \multicolumn{3}{|c|}{ Ratio of total indebtedness } & \multicolumn{3}{|c|}{ Long-term debt-to-equity } \\
\hline & Ols & EF & EA & Ols & $\mathrm{EF}$ & EA \\
\hline Tang & $\begin{array}{l}0.249 \\
(0.024)^{a}\end{array}$ & $\begin{array}{l}0.246 \\
(0.024)^{\mathrm{a}}\end{array}$ & $\begin{array}{l}0.249 \\
(0.024)^{a}\end{array}$ & $\begin{array}{l}0.215 \\
(0.023)^{a}\end{array}$ & $\begin{array}{l}0.213 \\
(0.023)^{a}\end{array}$ & $\begin{array}{l}0.215 \\
(0.023)^{\mathrm{a}}\end{array}$ \\
\hline Rent & $\begin{array}{l}-1.142 \\
(0.130)^{a}\end{array}$ & $\begin{array}{l}-1.167 \\
(0.121)^{\mathrm{a}}\end{array}$ & $\begin{array}{l}-1.143 \\
(0.118)^{a}\end{array}$ & $\begin{array}{l}-0.332 \\
(0.115)^{\mathrm{a}}\end{array}$ & $\begin{array}{l}-0.349 \\
(0.118)^{a}\end{array}$ & $\begin{array}{l}-0.332 \\
(0.115)^{\mathrm{a}}\end{array}$ \\
\hline Size & $\begin{array}{l}0.082 \\
(0.018)^{a}\end{array}$ & $\begin{array}{l}0.082 \\
(0.019)^{\mathrm{a}}\end{array}$ & $\begin{array}{l}0.082 \\
(0.018)^{\mathrm{a}}\end{array}$ & $\begin{array}{l}0.071 \\
(0.018)^{a}\end{array}$ & $\begin{array}{l}0.073 \\
(0.018)^{\mathrm{a}}\end{array}$ & $\begin{array}{l}\text { Execution time: } 0.066 \\
(0.018)^{a}\end{array}$ \\
\hline Mtb & $\begin{array}{l}0.097 \\
(0.014)^{\mathrm{a}}\end{array}$ & $\begin{array}{l}0.097 \\
(0.015)^{\mathrm{a}}\end{array}$ & $\begin{array}{l}0.096 \\
(0.015)^{\mathrm{a}}\end{array}$ & $\begin{array}{l}0.048 \\
(0.014)^{a}\end{array}$ & $\begin{array}{l}0.047 \\
(0.015)^{\mathrm{a}}\end{array}$ & $\begin{array}{l}-0.506 \\
(1954)^{\mathrm{a}}\end{array}$ \\
\hline Efwmb & $\begin{array}{l}0.005 \\
(0.009)\end{array}$ & $\begin{array}{l}0.004 \\
(0.009)\end{array}$ & $\begin{array}{l}0.005 \\
(0.009)\end{array}$ & $\begin{array}{l}-0.007 \\
(0.008)\end{array}$ & $\begin{array}{l}-0.007 \\
(0.009)\end{array}$ & $\begin{array}{l}-0.031 \\
(0.008)\end{array}$ \\
\hline Ibvmt & $\begin{array}{l}-4.37 \mathrm{E}-06 \\
(0.00004)\end{array}$ & $\begin{array}{l}-3.54 \mathrm{E}-06 \\
(0.0004)\end{array}$ & $\begin{array}{l}-4.37 \mathrm{E}-06 \\
(0.0004)\end{array}$ & $\begin{array}{l}9.38 \mathrm{E}-06 \\
(0.0004)\end{array}$ & $\begin{array}{l}8.42 \mathrm{E}-06 \\
(0.0004)\end{array}$ & $\begin{array}{l}9.38 \mathrm{E}-06 \\
(0.0004)\end{array}$ \\
\hline _Cons & $\begin{array}{l}-1.570 \\
(0.347)^{\mathrm{a}}\end{array}$ & $\begin{array}{l}-1.569 \\
(0.302)^{\mathrm{a}}\end{array}$ & $\begin{array}{l}-1.570 \\
(0.347)^{\mathrm{a}}\end{array}$ & $\begin{array}{l}-1.358 \\
(0.338)^{\mathrm{b}}\end{array}$ & $\begin{array}{l}-1.374 \\
(0.345)^{a}\end{array}$ & $\begin{array}{l}-1.358 \\
(0.338)^{a}\end{array}$ \\
\hline R2 adjusted & 0.8664 & 0.8663 & 0.8664 & 0.6935 & 0.6934 & 0.6935 \\
\hline R2 within & - & 0.8648 & 0.8648 & - & 0.6888 & 0.6887 \\
\hline R2 between & - & 0.9503 & 0.9516 & - & 0.8724 & 0.8782 \\
\hline $\mathrm{F}$ & $155.58^{a}$ & $148.20^{\mathrm{a}}$ & - & $54.31^{a}$ & $51.28^{\mathrm{a}}$ & - \\
\hline Wald & - & - & $933.47^{\mathrm{a}}$ & - & - & $325.83^{\mathrm{a}}$ \\
\hline $\mathrm{H}$ & - & 0.89 & & - & 0.84 & \\
\hline LM & - & - & 1.40 & - & - & 1.47 \\
\hline M1 & - & - & 0.789 & - & - & 0.897 \\
\hline $\mathrm{N}$ & 151 & 151 & 151 & 151 & 151 & 151 \\
\hline
\end{tabular}

These models explain moderately the levels of indebtedness of Tunisian businesses listed on the stock exchange. In fact, the coefficients of determination are high for both ratios of debt. For the two models, the probability of the test specification of Hausman is greater than the threshold of $10 \%$. In this case this test does not differentiate between the fixed-effects model and the random effects one. Of this fact, the two models (R2 within < r2 between) have led us to favor the random effects model. In addition, the probability of statistics of the test of Breush-Pagan shows that there is a problem of heteroscedasticity for both ratios of debt. Similarly, the test of Wooldridge shows that there is a problem of the first-order autocorrelation in tailings for both ratios of debt (Table 8).

The variable relative to the size is significant at $5 \%$ threshold for the two ratios of debt. From another point of view, the embodiment is significant at $1 \%$ threshold for all estimates. Similarly, the variable relative to profitability is significant. Also, it has a negative sign for a ratio of total debt. This result is consistent with the predictions of the theory of hierarchical funding.

The representative variable of liquidity is significant at the threshold of $1 \%$ and with a negative sign for the two ratios of debt. This negative relationship implies that the Tunisian businesses support current assets which are to their provisions in order to 
Table 8 Summary of results of carried out regressions

\begin{tabular}{|c|c|c|c|c|c|c|}
\hline \multirow{2}{*}{$\begin{array}{l}\text { The } \\
\text { variables }\end{array}$} & \multicolumn{3}{|c|}{ Ratio of total indebtedness } & \multicolumn{3}{|c|}{ Long-term debt-to-equity } \\
\hline & Ols & $\mathrm{EF}$ & EA & Ols & $\mathrm{EF}$ & EA \\
\hline Tang & $0.263(0.024)^{\mathrm{a}}$ & $0.261(0.024)^{\mathrm{a}}$ & $0.263(0.024)^{a}$ & $0.235(0.023)^{a}$ & $0.234(0.023)^{a}$ & $0.235(0.023)^{a}$ \\
\hline Rent & $-1.037(0.123)^{\mathrm{a}}$ & $-1.044(0.126)^{a}$ & $\begin{array}{l}-1.035 \\
(0.123)^{a}\end{array}$ & $-0.177(0.130)$ & $-0.191(0.120)$ & $-0.177(0.130)$ \\
\hline Size & $0.056(0.022)^{b}$ & $0.058(0.022)^{b}$ & $0.056(0.022)^{b}$ & $0.049(0.021)^{b}$ & $0.049(0.021)^{\mathrm{b}}$ & $0.049(0.021)^{b}$ \\
\hline Oc & $-0.697(2.090)$ & $-0.671(2.120)$ & $-0.697(2.090)$ & $-2.203(1.989)$ & $-2.109(2.018)$ & $-2.202(1.989)$ \\
\hline Liq & $\begin{array}{l}-0.025 \\
(0.008)^{a}\end{array}$ & $\begin{array}{l}-0.025 \\
(0.008)^{a}\end{array}$ & $\begin{array}{l}-0.026 \\
(0.008)^{a}\end{array}$ & $\begin{array}{l}-0.031 \\
(0.008)^{a}\end{array}$ & $\begin{array}{l}-0.030 \\
(0.008)^{\mathrm{a}}\end{array}$ & $\begin{array}{l}-0.031 \\
(0.008)^{\mathrm{a}}\end{array}$ \\
\hline $\mathrm{Rd}$ & $-0.012(0.015)$ & $-0.011(0.016)$ & $-0.013(0.015)$ & $-0.022(0.0145)$ & $-0.022(0.015)$ & $-0.022(0.015)$ \\
\hline Def & $\begin{array}{l}-1.83 E-11 \\
(6.49 E-10)\end{array}$ & $\begin{array}{l}1.99 \mathrm{e}-11 \\
(6.72 \mathrm{E}-10)\end{array}$ & $\begin{array}{l}-1.83 \mathrm{E}-11 \\
(6.49 \mathrm{E}-10)\end{array}$ & $\begin{array}{l}4.60 \mathrm{e}-10 \\
(6.18 \mathrm{E}-10)\end{array}$ & $\begin{array}{l}4.24 \mathrm{e}-10 \\
(6.39 \mathrm{E}-10)\end{array}$ & $\begin{array}{l}4.60 \mathrm{e}-10 \\
(6.18 \mathrm{E}-10)\end{array}$ \\
\hline Mtb & $0.094(0.016)^{a}$ & $0.094(0.016)^{a}$ & $0.094(0.016)^{\mathrm{a}}$ & $0.047(0.015)^{a}$ & $0.046(0.015)^{a}$ & $0.047(0.014)^{a}$ \\
\hline Efwmb & $0.004(0.009)$ & $0.004(0.009)$ & $0.003(0.009)$ & $-0.008(0.008)$ & $-0.007(0.009)$ & $-0.008(0.008)$ \\
\hline Ipset & $\begin{array}{l}0.00003 \\
(0.0004)\end{array}$ & $\begin{array}{l}0.00003 \\
(0.0004)\end{array}$ & $\begin{array}{l}0.00003 \\
(0.0004)\end{array}$ & $\begin{array}{l}-1.20 \mathrm{E}-06 \\
(0.0004)\end{array}$ & $\begin{array}{l}0.00003 \\
(0.0004)\end{array}$ & $\begin{array}{l}-1.20 \mathrm{E}-06 \\
(0.0004)\end{array}$ \\
\hline _Cons & $\begin{array}{l}-1.130 \\
(0.405)^{a}\end{array}$ & $\begin{array}{l}-1.088 \\
(0.405)^{\mathrm{a}}\end{array}$ & $\begin{array}{l}-1.130 \\
(0.406)^{\mathrm{a}}\end{array}$ & $\begin{array}{l}-0.863 \\
(0.386)^{b}\end{array}$ & $\begin{array}{l}-0.876 \\
(0.385)^{b}\end{array}$ & $\begin{array}{l}-0.863 \\
(0.386)^{b}\end{array}$ \\
\hline R2 adjusted & 0.8766 & 0.8759 & 0.8766 & 0.7307 & 0.7306 & 0.7307 \\
\hline R2 within & - & 0.8744 & 0.8744 & - & 0.7253 & 0.7252 \\
\hline R2 between & - & 0.9572 & 0.9712 & - & 0.9385 & 0.9407 \\
\hline F & $98.78^{a}$ & $104.47^{a}$ & - & $37.71^{a}$ & $39.60^{a}$ & - \\
\hline Wald & - & - & $987.81^{\mathrm{a}}$ & - & - & $377.11^{\mathrm{a}}$ \\
\hline H $P$-values & - & $0.50(0.0000)$ & & - & 0.52 & \\
\hline LM & - & - & 2.13 & - & - & 2.09 \\
\hline M1 & - & - & $9.144^{b}$ & - & - & $9.002^{b}$ \\
\hline $\mathrm{N}$ & 150 & 150 & 150 & 150 & 150 & 150 \\
\hline
\end{tabular}

${ }^{\mathrm{a}}$ Significant at $1 \%$ level

bSignificant at the threshold of 5\%

*Significant at the threshold of $10 \%$

$\mathrm{F}$ is a test of overall significance of Fisher; Wald is a Wald test of joint significance of specific variables to firms; $\mathrm{H}$ is a test of a specification of Hausman; LM is a test of heteroscedasticity of Breush-Pagan; M1 is a test of autocorrelation of order 1 of Wooldridge; the standard deviations are carried over between parentheses

finance their investments. The risk of default is not significant for the two versions of debt ratio. This result indicates that this variable does not affect the decisions related to the use of debt.

The variable on the opportunities of growth is not significant for both ratios of debt. The negative sign associated with this variable is consistent with the predictions of theories of "Trade-Off" and "pecking order". Thus, the theoretical frameworks consider that this variable affects the debt-equity ratios of companies negatively. Similarly, this negative relationship is contrary to that obtained in the developed works by Dalbor and Upneja (2004).

The variable of the deficit of funding is not significant for both ratios of debt and aims a low coefficient inversely to the predictions of the theory of "pecking order" which attaches great importance to this variable. In fact, we can conclude that this variable affects weakly the decisions on the funding of Tunisian firms.

As regards to the ratio MTB, it is significant to the threshold of $1 \%$ and positive for both ratios of debt, while the weighted average of the ratio of MTB and the variable IPSET are still not significant for versions of debt ratios. 
In fact, we can conclude that the assessments affect very weakly debt the ratios of Tunisian businesses listed on the stock exchange.

The study of El Amri and al (2015) investigates five determinants of capital structure (leverage) in three subsectors of the Omani Industrial companies (food, construction and chemical) listed on Muscat Securities Market for the period 2008-2012.

The capital structure or leverage is measured by total debt ratio. In the industrial sector as a whole; the findings of the study indicate that there is a statistically positive association between risk and tangibility and leverage. Also, there is a statistically negative association between growth rate and profitability and leverage, while there is no association with size. Regression analysis indicates that size, tangibility and risk have a statistically significant effect on leverage.

\section{Conclusion}

In terms of this analysis, the theory of "Trade-Off" brings a better explanatory power on the variations of structures of the capital of Tunisian companies listed on the stock exchange.

The results obtained have demonstrated that the introduction of all the variables from the various theoretical frameworks has helped to increase the explanatory power of the model. These results lead us to conclude that the confrontations and attempts that tend to promote a theoretical framework in relation to others do not seem to be justified. In addition, the combination of these various theories allows the improvement of the explanation and the analysis in terms of financial structures of firms.

The research focused on the financial structure of Tunisian companies. It was part of the work that attempted to validate the explanatory theories of the determinants of the financial structure of firms empirically.

A brief overview of the contributions to the debate on the financial structure was presented in the first section. In the last section, the compromise theory which asserts the existence of an optimal ratio of the debt that the companies seek to achieve. The theory of hierarchical financing preferences has been tested, where companies follow a hierarchy financed by the need for funds. For this purpose, the estimate was made on a panel of data from 26 listed Tunisian companies belonging to the industrial sectors. The estimation is carried out by the panel method of data for the period from 2005 to 2010. The empirical results showed that the indebtedness of the Tunisian companies is explained by the desire to reach a target ratio of debt and not by the need of external funds.

However, several limitations characterize our research: In the first place, this study concerned only 26 listed companies (the banks were eliminated) and the period of analysis used only extends over 6 years due to insufficient accounting and financial data for the listed companies that belong to Industrial sectors. In order to have more accounting information and extend the analysis over a longer period, a subsequent study will cover all listed companies in Tunisia. Second, the "Trade-off" theory which states that the financial structure of firms depends on market conditions, has not been the subject of empirical verification. A subsequent study will carry out an empirical check in this direction. In addition, other variables that may influence the financial structure have not been identified. In the present study only variables from the compromise theory and that of the hierarchical preferences of financing were selected. Like any research work, this study has some limits. First, the Tunisian stock market is very modest 
in terms of number of listed companies which justifies our small sample. Secondly, we find that the coefficients of determination are low for the regression model which indicates a poor linear fit. Introducing aspects of behavioral finance such as over confidence and optimism could be a new insight into the theory of capital structure. Further studies are also suggested to examine the impact of national culture and religion on capital structure choice.

\section{Endnotes}

${ }^{1}$ However it is to be noted that the empirical relevance of a behavior of "timing" is not new. Several studies prove that the emissions of own capital coincide with high estimations of the market come from: Taggart (1977), Marsh, Lucas and McDonald (1990) and kung, Kim and Stulz (1996).

\section{Acknowledgements}

The authors thank Dr. Ryhab Ben Fredj for technical assistance and for constructing the model.

\section{Funding}

This research received no specific grant from any funding agency in the public, commercial, or not-for-profit sectors.

\section{Authors' contributions}

Study conception, Literature search, figures and study design: Asma Sghaier \& Hanen Khaireddine. Acquisition of data: Zouhayer Mighri. Analysis and interpretation of data: Mohamed Soufeljil. Drafting of manuscript: Asma Sghaier. Critical revision: All authors are contributed equally. All authors read and approved the final manuscript.

\section{Authors' information}

Asma Sghaier: ISG Sousse, LaREMFiQ (University of Sousse) Tunisia, Competing interest: Islamic Finance, Corporate Finance, accounting. (corresponding author).

Mohamed Soufeljil: ISG Sousse, Tunisia/ E-mail: soufeljil.m@gmail.com, Competing interest: Islamic Finance, Corporate Finance, Management \& Business.

Mighri Zouhayer: Doctor HDR Financial and Accounting Assistant Professor at university of Sfax, Tunisia (ISAAS),

LARTIGE, Phone: + (216) 97900023, Competing interest: Islamic Finance, Corporate Finance, Management \& Business. Hanène Kheireddine: PhD Student, Faculty of Economics and Management, Sfax Tunisia, LARTIGE (Tunisia), Competing interest: Islamic Finance, Corporate Finance, Management \& Business, economic.

\section{Competing interests}

The authors declare that they have no competing interests.

\section{Publisher's Note}

Springer Nature remains neutral with regard to jurisdictional claims in published maps and institutional affiliations.

\section{Author details}

${ }^{1}$ the ISG Sousse, Sousse, Tunisia. ${ }^{2}$ the ISG Sousse, LaREMFiQ, University of Sousse, Sousse, Tunisia. ${ }^{3}$ LARTIGE, FSEG University of Sfax, Sfax, Tunisia. ${ }^{4}$ Faculty of Economics and Management, Sfax, Tunisia.

Received: 10 November 2016 Accepted: 4 October 2017

Published online: 24 October 2017

\section{References}

Adedeji, A. (1998). Does the pecking order hypothesis explain the dividend payout ratios of firms in the UK? Journal of Business Finance and Accounting, 25, 1127-1155.

Al-Najjar, B, \& Kilincarslan, E. (2016). The effect of ownership structure on dividend policy: evidence from Turkey, Corporate Governance. The International Journal of Business in Society, 16(1), 135-161 https://doi.org/10.1108/CG-09-2015-0129.

Alti. (2005). IPO market timing. The Review of Financial Studies, 18(3), 1105-1138.

El Amri and Al. (2015). Les Facteurs de la Pauvreté Hydrique du Grand Sousse : Un Déséquilibre en eau Agricole en Perspective?, European Journal of Scientific Research, ISSN 1450-216X / 1450-202X 1363 320-335, http://www. europeanjournalofscientificresearch.com

Arellano, \& Bond. (1991). Some tests of specification for panel data: Monte Carlo evidence and an application to employment equations. The Review of Economic Studies, 58(2), 277-297.

Autore, D, \& Kovacs, T. (2009). Equity issues and temporal variation in information asymmetry. Journal of Banking and Finance, 34, 12-23.

Bacha, S, \& Attia, T. (2016). Ownership structure, financial communication quality and debt cost: An empirical study of Tunisian listed companies. International Journal of Business and Finance Management Research, V4, 109-116.

Barclay, MJ, \& Smith, C. (1995). The maturity structure of corporate debt. Journal of Finance, 50, 609-631.

Becker, M, \& Wurgler, J. (2002). Market timing and capital structure. Journal of Finance, 57, 1-32. 
Benito A. (2003). The Capital Structure decisions of firms: Is there a pecking order?, Documento de Trabajo, Banco de Espana, pp. 1 - 41.

Berk, J, \& DeMarzo, P (2008). Corporate Finance, Statistics and Computing. Boston: Pearson International Edition ISBN 0321-41680-5.

Berle, A. and Means, G. (1956), The Modern Corporation and private property, 2th ed., New York, MacMillan,

Bias, B, Hillion, P, Malecot, JF. (1995). The financial structure of firms: A empirical investigation on the French data? Economics and Forecasting, 120, 15-27.

Booth, \& Al. (2001). TEMPORARY JOBS: STEPPING STONES OR DEAD ENDS? The Economic Journal, 112(480), F189-F213.

Borisova, G, Fotak, V, Holland, K. (2015). Government ownership and the cost of debt in publicly traded firms. The Journal of Finance, 98-119.

Boyd, BK, \& Solarino, AM. (2016). Ownership of corporations: A review, synthesis and research agenda. Journal Manage, $42,1282-1314$

Bradley, M, Jarrell, GA, Kim, EH. (1984). On the existence of an optimal capital structure: Theory and evidence. Journal of Finance, 39, 857-878.

Breusch, TS, \& Pagan, AR. (1979). A Simple Test for Heteroscedasticity and Random Coefficient Variation. Econometrica, $47,1287-1294$.

Chen, JJ. (2004). Determinants of capital structure of Chinese-listed companies. Journal of Business Research, 57, 1341-1351.

Chirinko, RS, \& Singha, AR. (2000). Testing static trade-off against pecking order models of capital structure: A critical how. Journal of Financial Economics, 58, 417-425.

Chniguir M, Sghaier A, Soufeljil M, Mighri Z. (2017). The degree of Home Bias in the holding of share portfolio: case of American investors. International Journal of Sustainable Economies Management (IJSEM).

Dalbor, \& Upneja. (2004). The investment opportunity set and the long-term debt decision of US lodging firms. Journal of Hospitality \& Tourism Research, 28(3), 346-355.

Dang, VA, Kim, M, Shin, Y. (2014). Asymmetric capital structure adjustments: New evidence from dynamic pane threshold models. Journal of Empirical Finance, 19(4), 465-482 http://dx.doi.org/10.1016/j.jempfin.2012.04.004.

DeAngelo, H, \& Masulis, RW. (1980). Optimal capital structure under corporate and personal taxation. Journal of Financial Economics, 8, 3-29.

Delcour, L. (2006). La politique de voisinage et les relations russo-européennes : partenariat stratégique ou lutte d'influence? Etudes Européennes.

DeMiguel, A, \& Pindado, J. (2001). Determinants of Capital Structure: New Evidence from Spanish Panel data. Journal of Corporate Finance, 7, 77-99.

Fama, EF, \& French, KR. (1997). Industry costs of equity. Journal of financial economics, 43(2), 153-193.

Fama, E, \& French, K. (2002). Testing Trade-Off and pecking order predictions about dividends and Debt. Review of Financial Studies, 15, 1-33.

Fama, EF, \& French, KR. (2005). Financing decisions: who issues stock? Journal of Financial Economics, 76(3), 549-582 https://doi.org/10.1016/j.jineco.2004.10.003.

Flannery, \& Rangan. (2006). Partial adjustment toward target capital structures. Journal of Financial Economics, 79(3), 469-506.

Frank, M, \& Goyal, K. (2003). Testing the pecking order theory of capital structure. Journal of Financial Economics, 67, 217-248.

Frank, Mr, \& Goyal, K. (2005). Trade-Off and pecking theories of debt, forthcoming, Handbook of Corporate Finance: Empirical Corporate Finance, flight 1.

Frank, MZ, \& Goyal, VK (2008). In BE Eckbo (Ed.), Tradeoff and pecking order theories of debt, (vol. 2, pp. 135-202). North Holland: Handbook of Corporate Finance: Empirical Corporate Finance.

Graham, A. (2000). How big are the tax benefits of debt? The Journal of Finance, 55(5), 1901-1941.

Harris, M, \& Raviv, A. (1990). Capital structure and the informational role of debt. The Journal of Finance, 45(2), 321-349.

Harris, M, \& Raviv, A. (1991). The theory of capital structure. The Journal of Finance, 46(1), 297-355.

Hausman. (1978). Specification tests in econometrics. Econometrica, 46(6), 1251-1271 Published by: The Econometric Society.

Hertig. (1998). Corporate Governance in the United States as Seen from Europe, Columbia Business Law Review 1998 Colum. Bus. L. Rev. (1998) N1 pp 27-50.

Hovakimian, A. (2006). Are observed structures capital determined by equity market timing? Journal of Financial and Quantitative Analysis, 41, 221-243.

Hovakimian, A, \& Li, G. (2011). In search of conclusive evidence: How to test for adjustment to target capital structure. Journal of Corporate Finance, 17(1), 33-44 http://dx.doi.org/10.1016/j.jcorpfin.2010.07.004.

Huang, R. (2009). Testing theories of Capital Structure and estimating the speed of adjustment. Journal of Financial and Quantitative Analysis, forthcoming.

Huang, R, \& Ritter, JR. (2005). Testing the market timing theory of capital structure. Journal of Financial and Quantitative Analysis, 1, 221-246 http://dx.doi.org/10.2139/ssrn.938564.

Huang, R. \& Ritter, R. (2006). Testing the market timing Theory of Capital Structure, Working Paper, University of Florida.

Jensen, M. (1986a). Agency costs of free cash FlowCorporate finance and takeovers. American Economic Review, 76, 323-329. Jensen, MC. (1986b). Agency costs of free cash flow, corporate finance, and takeovers. The American economic review, 76(2, Papers and Proceedings of the Ninety-Eighth Annual Meeting of the American Economic Association), 323-329.

Jensen, M, \& Meckling, W. (1976). Theory of the firm: Managerial behavior, agency costs, and ownership structure. Journal of Financial ECONOMIES, 3, 305-360.

Joeveer, K. (2013). Firm, country and macroeconomic determinants of capital structure: Evidence from transition economies. Journal of Comparative Economics, 41, 294-308 http://dx.doi.org/10.1016/j.jce.2012.05.001.

Kayhan, \& Titman. (2006). Firms' histories and their capital structures. Journal of Financial Economics, 83(1), 1-32. Kennedy. (1985). Functional Endoscopic Sinus Surgery Technique. Arch Otolaryngol, 111(10), 643-649.

Kötter, M, Koch, CT, Buch, C. (2009). Margins of international banking: Is there a productivity pecking order in banking, too? CESifo Working Paper, 2891.

Kouki, \& Guizani. (2009). Ownership structure and dividend policy evidence from the Tunisian stock market. European Journal of Scientific Research, ISSN 1450-216X, 25(1), 42-53. 
Kung, K, \& Stulz. (1996). Timing, investment opportunities, managerial discretion, and the security issue decision. Journal of Financial Economics, 42(2), 159-186.

Leary, \& Roberts. (2005). Do firms rebalance their capital structures. The Journal of Finance, 60(6), 2575-2619.

Lenz, C, \& Al. (2015). The economics of disclosure and financial reporting regulation. Journal of Accounting Research, 45-57.

Lucas, DJ, \& McDonald, RL. (1990). Equity issues and stock price dynamics. The Journal of Finance, 45(4), 1019-1043.

Marsh, Lucas and McDonald (1990), " Equity issues and stock price dynamics", The Journal of Finance, Volume 45, Issue 4, September 1990, Pages 1019-1043

Martínez-Ferrero, J, Garcia-Sanchez, IM, Cuadrado-Ballesteros, B. (2013). Effect of financial reporting quality on sustainability information disclosure. Corporate Social Responsibility and Environment Management., 22, 45-64.

Miller, EM. (1977). Risk, uncertainty, and divergence of opinion. The Journal of Finance, 32(4), 1151-116.

Modigliani, F, \& Miller, M. (1958). The cost of CapitalCorporate finance and the theory of investment. American Economic Review, 48, 261-297.

Modigliani, F, \& Miller, M. (1963). Corporate income Taxs and the cost of capital. American Economic Review, 261-297.

Myers, SC. (1984). The Capital Structure Puzzle. The Journal of Finance, 39(3), 574-592.

Myers, SC, \& Majluf, SN. (1984). Corporate financing and investment decisions when firms have information that investors do not have. Journal of Financial Economics, 13, 187-221.

Ozkan, A. (2001). Determinants of Capital Structure and Adjustment to Long Run Target: Evidence From UK Company Panel Data. Journal of Business Finance \& Accounting, 28(1-2), 175-198.

Oztekin, O, \& Flannery, MJ. (2012). Institutional determinants of capital structure adjustment speeds. Journal of Financial Economics, 103(1), 88-112 http://dx.doi.org/10.1016/j.jfineco.2011.08.014.

Pfister B. \& Schwarger M. (2016). Assessing the impact of corporate reputation on firm's cost debt: An empirical study of German DAX30 companies. In: Marketing challenges in a turbulent business environment.

Rajan, \& Zingales. (1995). What Do We Know about Capital Structure? Some Evidence from International Data. The Journal of Finance, 50(5), 1421-1460.

Shleifer, A, \& Vishny, RW. (1997). A survey of corporate governance. Journal of Finance, 52, 737-783.

Shyam, S, \& Myers, SC. (1999). Testing trade-off against pecking order models of capital structure. Journal of Financial ECONOMIES, 17-36.

Soufeljil, M, Sghaier, A, Kheireddine, H, Mighri, Z. (2016a). Ownership structure and corporate performance : The case of listed Tunisian firms. Journal of Business \& Financial Affairs, 5(4), 1-8.

Soufeljil M, Sghaier A, Kheireddine H \& Mighri Z. (2016b). Managerial property, strategic resources and diversification of enterprises: Case of Tunisian businesses rated G. Journal of Economics and Business Oct.2016,(GJEB) 1 (2) (2016),pp 89-101.

Taggart. (1977). A model of corporate financing decisions. The Journal of Finance, 32(5), 1467-1484.

Tang, \& Yang. (2007). Phosphor-free white-light light-emitting diode of weakly carrier-densitydependent spectrum with prestrained growth of quantum wells. Appl. Phys. Lett., 90, 151122.

Titman, \& Wessels. (1988). The Determinants of Capital Structure Choice. The Journal of Finance, 43(1), 1-19.

Welch, I. (2004). Capital Structure and Stock Returns. Journal of Political Economy, 112(1).

Wooldridge. (2002). Cluster-sample methods in applied econometrics. The American Economic Review, 93(2, Papers and Proceedings of the One Hundred Fifteenth Annual Meeting of the American Economic Association, Washington, DC, January 3-5, 2003 (May, 2003)), 133-138.

Zerriaa, \& Noubbigh. (2015). Determinants of Capital Structure: Evidence from Tunisian ListedFirms. International Journal of Business and Management, 10(9), 121-135.

Zou, \& Xiao. (2006). The financing behaviour of listed Chinese firms. The British Accounting Review, 38(3), 239-258.

\section{Submit your manuscript to a SpringerOpen ${ }^{\circ}$ journal and benefit from:}

- Convenient online submission

- Rigorous peer review

- Open access: articles freely available online

- High visibility within the field

- Retaining the copyright to your article

Submit your next manuscript at $\gg$ springeropen.com 